\title{
Hydrogeological structures as burried valley along the Eastern Pomerania Polish coast of the Baltic Sea
}

\author{
Anna Szelewicka ${ }^{1}$ \\ ${ }^{1}$ Marine Branch of Polish Geological Institute NRI, 5 Kościerska str., 80-328 Gdańsk
}

\begin{abstract}
One of the characteristic feature of geological structure of the southern Baltic coast is presence of deep structures in Pleistocene sediments. Meaning of deep aquifers is unmeasurably important for water economy. The water bearing structures are situated in substantial depth and are better isolated from the surface than the water of shallow aquifers. It has important meaning for natural protection of these waters. Water resource of the structure is substantially increase in case when in water drainage zone where regional and local water circulation are focused. Simultaneously hydrogeological parameters of Pleistocene strata in the frame of deep structure are considerably advantageous rather than parameters of deeper aquifers.
\end{abstract}

\section{INVESTIGATED AREA}

Recognition and estimation of hydrogeological conditions of buried valley structure fulfilled with Pleistocene sediment was the main object of research work of Marine Branch of Polish Geological Institute, Gdańsk. The scope of research work has been attached to frame of sheets of Geological Map and Hydrogeological Map of Poland in scale 1:50 000.

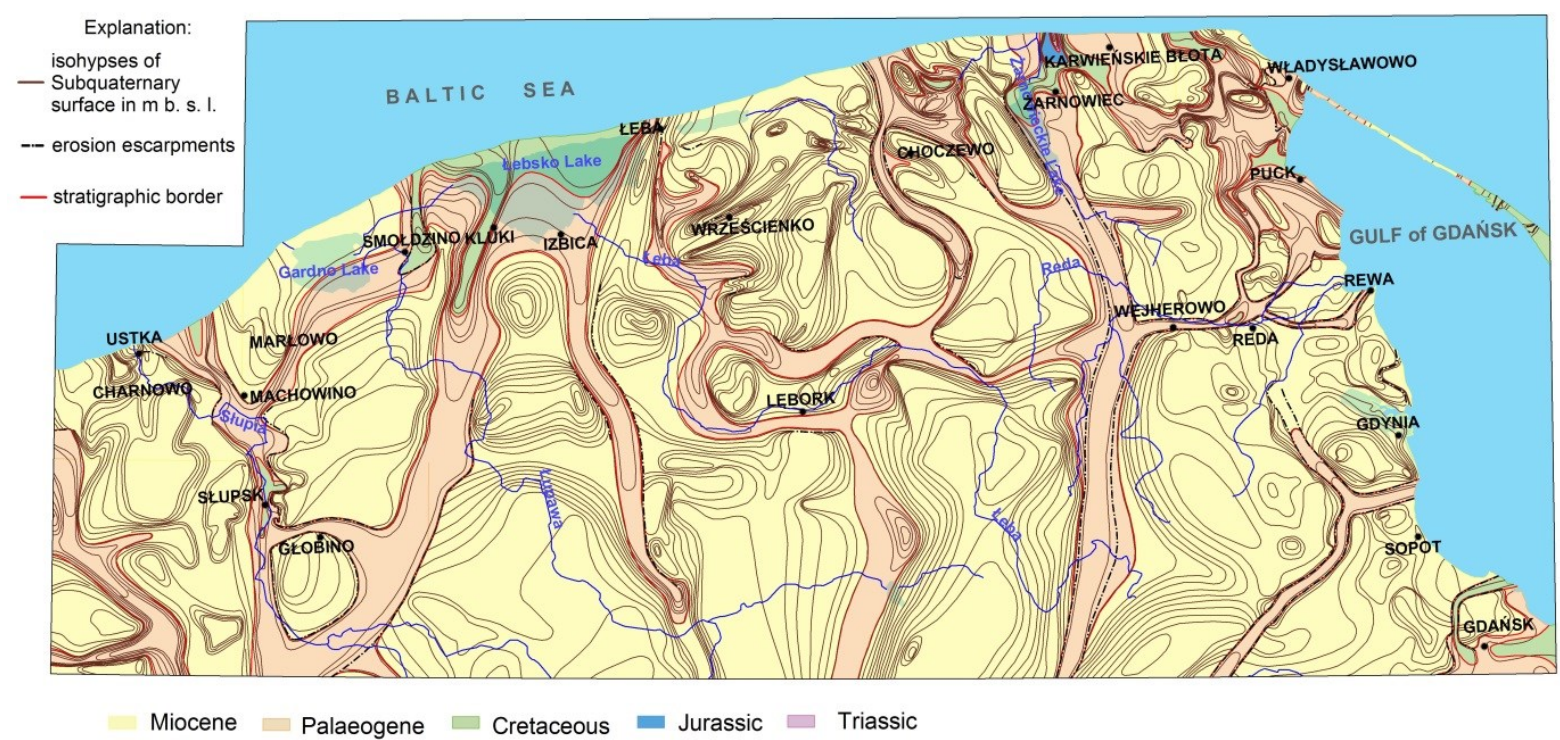

Figure 1. Subquaternary surface of the Eastern Pomerania Baltic coast (A. Szelewicka, 2011).

Elaboration of verified map of forming Subquaternary surface has allowed to singling out sequence of very often attached together long and narrow erosive structures and extensive depressions. Among this structures it is possible to differ two fundamental directions of their courses approximated for meridian and for parallel directions. Some structures like for example Łeba structure and others structures, where preferred by outflow of underground waters to Baltic sea. 


\section{GEOLOGY AND HYDROGEOLOGY}

Considerable part of area is occupied by moraine plateaus and by washed out material and partly of frontal moraine hills. Most often it is sediment connected with the last Pleistocene glaciation. The Reda-Łeba glacial valley and seaside lowlands together with lake consist of loamy and peat sediments and dunes. Oligocene or Eocene formations, sometime even Cretaceous and exceptionally within Żarnowiec structure the older strata of Mesozoic are disclosed of the buried valley directly under Quaternary. Inside erosional structures has reached to Triassic formation and erosion of sediments has reached to $320 \mathrm{~m}$ b.s.l. Inside construction of Quaternary substratum are clearly presented three areas of Subquaternary surface which were named for the purpose of this elaboration as follows: Lowering of Łebsko Lake (I), Lowering of Puck (II) and Lowering of Vistula delta plane (III). Profile of Quaternary sediments starts at the oldest Scandinavian glaciation. Lowering of Subquaternary surface are fulfilled in general by glaciofluvial sediments and glacial tills. In the remaining area on formation of older substratum mainly Miocene sediments the Saalian and Elsterian sediments have been stated. Pleistocene sediments are ended by formation Vistulian glaciation. Lithological forms create complicated structures in plane and in geological profile where sandy deposits predominate and vertical glacial tills strata are separated and very often divided by sandy strata. Groundwater within different Quaternary aquifers occur in sands and gravel deposits of glaciations. The hydraulic headlines of deep Quaternary and Oligocene aquifer is presented on the map given on fig. 2.

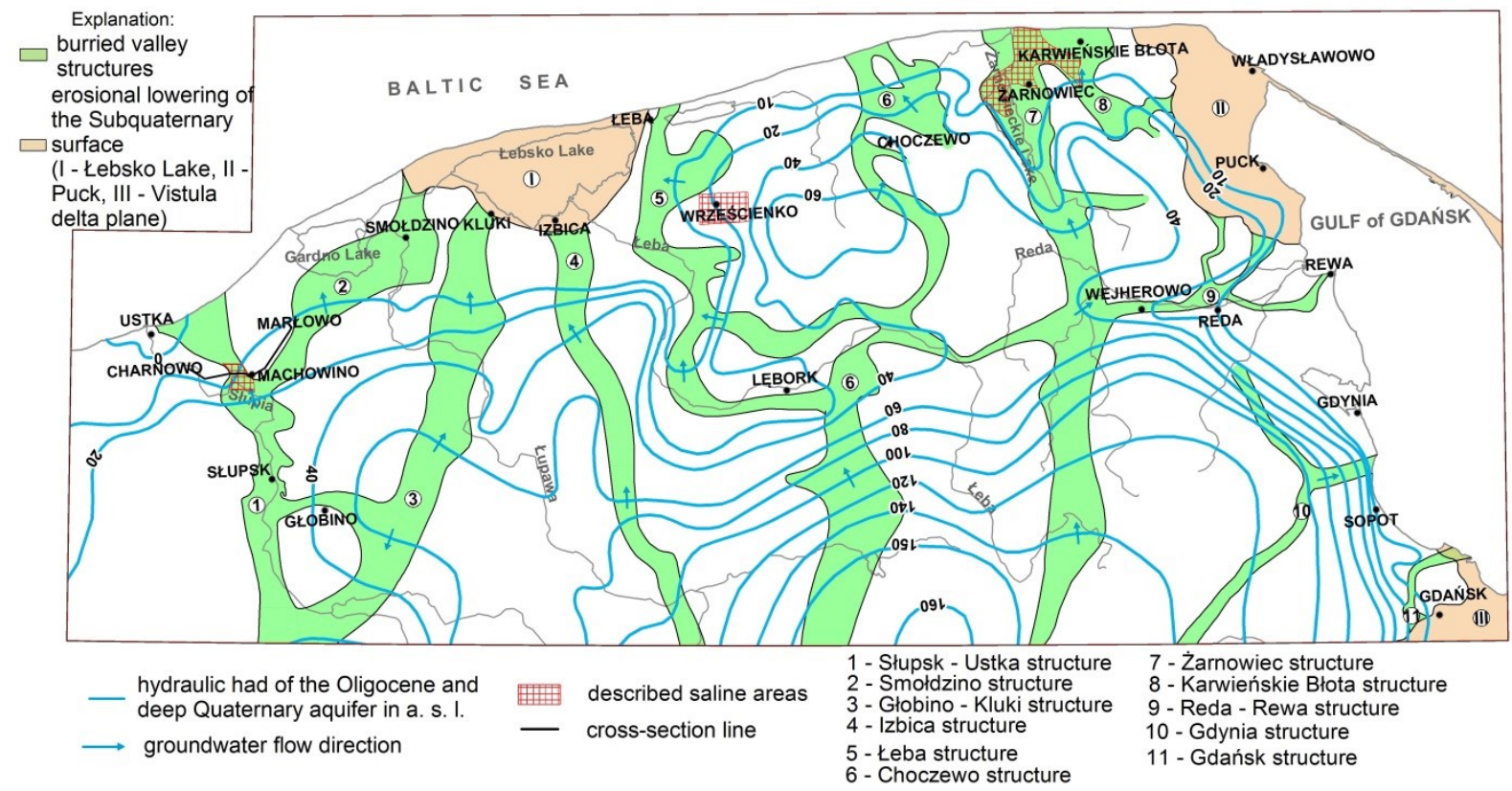

Figure 2. Scheme of the groundwater flows on the Eastern Pomerania coastal zone (A. Szelewicka, 2011).

Within structures of burried valley mainly slightly mineralized waters type HCO-Ca are observed. Salt water of Cl-Na type was stated in the areas of maximum depth of structures. The problem of salinity within Łeba structure was researched in drill hole in the area of Wrześcienko village, east direction from the structure. Concentration of chloride Ion in water was examined in this drilling hole in Wrześcienko on various depth:

- $12 \mathrm{mgCl} / \mathrm{dm}^{3}$ on depth $84,0-96,0(\mathrm{Q})$ - nearby drilling hole,

- $726 \mathrm{mgCl} / \mathrm{dm}^{3}$ on depth $144,0-160,0 \mathrm{~m}(\mathrm{~K})$,

- $7221 \mathrm{mgCl} / \mathrm{dm}^{3}$ on depth $334,0-348,0 \mathrm{~m}(\mathrm{~K})$,

- $79780 \mathrm{mgCl} / \mathrm{dm}^{3}$ on depth $374,0-600,0 \mathrm{~m}(\mathrm{~K})$. 
Appearance of salinity in deep level of Cainozoic most probably should be linked with ascesion of salt water from Mesozoic strata. It has been stated concentration of chloride Ion in water in the area of Łeba caused by fossil water - Mesozoic brine (B. Kozerski, M. Pruszkowska 1996). Water in Słupsk - Ustka structure are low mineralized with concentration of chloride Ion from several to approx. $40 \mathrm{mgCl} / \mathrm{dm}^{3}$ with mean value $18 \mathrm{mgCl} / \mathrm{dm}^{3}$. Only in area where sampling from structure in the deepest aqueous layer was extracted it was observed very high concentration of chloride Ion maximum up to $855 \mathrm{mgCl} / \mathrm{dm}^{3}$ in Machowino.

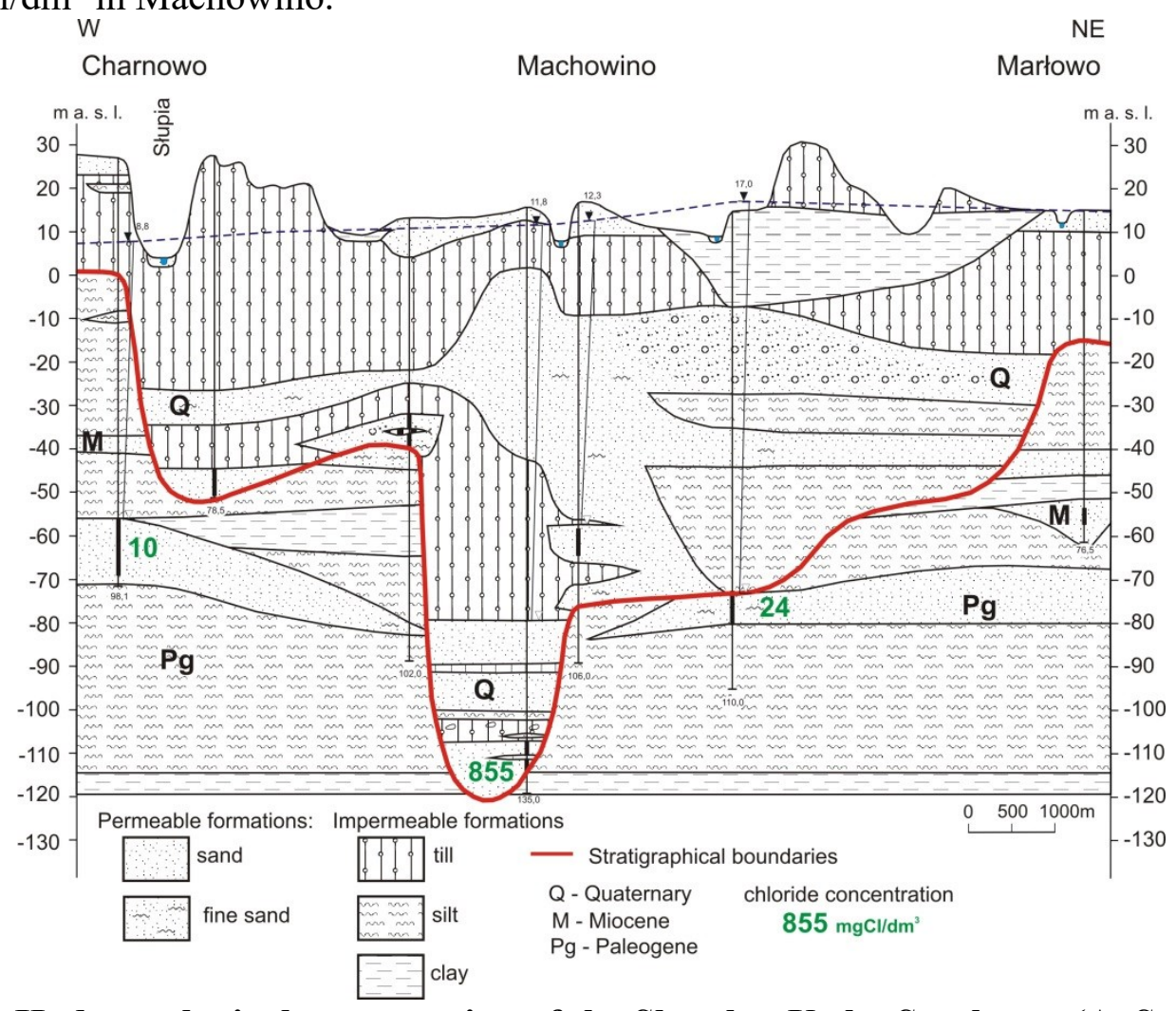

Figure 3. Hydrogeological cross-section of the Słupsk - Ustka Strukture (A. Szelewicka, 2011).

\section{CONCLUSIONS}

Groundwater intakes in the polish coastal Baltic zone cause the mixing of salt waters from ascension with the brackish waters from the intrusion of Baltic waters. Salt waters have been recognised in the deep valley structures, that enables ascension of brines from Mesozoic and Palaeozoic strata. This issue is very important from the perspective of water resources management and protection.

\section{REFERENCES}

Detailed Geological Map in scale 1:50 000 (number 1-7, 9-16, 20-27)), Polish Geological Institute NRI. Warsaw

Kozerski B., Pruszkowska M., 1996 - Range and ingression process of brackish see water into aquifers of eastern Baltic Coast. Unpublished [in Polish], Technical University of Gdańsk.

Szelewicka A., 2011 - Recognition of water - bearing strata in burried valley structures in the northern part of Polish Lowlands. Unpublished [in Polish], Polish Geological Institute - NRI, Marine Branch of Gdańsk. 